\title{
Financing of Terrorism: Following the Money
}

\author{
Mark Pieth*
}

\section{Introduction}

Combating money laundering or, to borrow a phrase, 'following the money', has developed into one of the most dynamic concepts in financial regulation and criminal law over the past decade. The paradigm has turned out to be extremely flexible; first applied in a limited field to describe the accumulation of capital generated on illegal markets, it is now used as a catch-all phrase for the management of ill-gotten gains from all possible sources. It is hardly surprising then that once the first shock after the 11 September terrorist attacks had subsided, governments, ${ }^{1}$ financial institutions ${ }^{2}$ and later also international organizations ${ }^{3}$ started to develop the concept of a coordinated fight against terrorism. In fact, one might ask why existing policies had not been more rigorously implemented before that date. ${ }^{4}$ As early as 1980, the first document in Europe conceptualizing the term 'money laundering's did not focus on drug trafficking, rather it sought a means of tracking the ill-gotten gains of hijacking and robbery by left-wing terrorists, especially in Italy and Germany ('Red Brigades' and 'Red Army Faction'). Furthermore, the UN had already negotiated a series of instruments against terrorism ${ }^{6}$ before 11 September, some of which were only ratified by the majority of member states after the attacks of last fall.

The question why the anti-money-laundering-concept was not applied more rigorously to terrorist groups, such as the IRA, ETA and others, that have long been in existence is certainly a valid one. The suspicion arises that political difficulties in

* Professor, Criminal Law at University of Basel.

1 For US: Cf. 'USA Patriot Act', H.R. 3162 <www.politechbot.com/docs/usa.act.final. $102401 . h \mathrm{tml}>$.

2 Cf. 'Wolfsberg Statement, the Suppression of the Financing of Terrorism'.

3 FATF, Special Recommendations on Terrorist Financing, 31 October 2001.

4 If they had been, why would many countries now be drafting more stringent legislation?

5 Council of Europe: R(80) 10 of 27 June 1980.

6 GA Res. 49/60, 9 December 1994; GA Res. 51/210, 17 December 1996; GA Res. 52/164 and 165, 15 December 1997; GA Res. 53/108, 8 December 1998; GA Res. 54/109, 9 December 1999, launching the International Convention for the Suppression of the Financing of Terrorism and the Security Council Res. 13/73.

European Journal of Law Reform, Vol. 4, No. 2

(C) Kluwer Law International 2002. 
drawing a clear line between 'freedom fighters' and 'terrorists' blocked the necessary consensus. After 11 September, everything seems quite different: the UN, the Financial Action Task Force (FATF) and others are now focusing their efforts on controlling the 'financing of terrorism' and have immediately attempted to apply the concept commonly used for the control of money laundering for this purpose. ${ }^{7}$

International agendas come about through pragmatic reactions to events. The problem, however, demands a more fundamental discussion of the wider context of the development of the paradigm. Going back in time to the mid 1980s, when 'money laundering' became a household word throughout the world, the aim at that time and subsequently focused mainly on impeding the financing and re-financing of illicit drug-trafficking. Within the field of criminal law, international standards promoted three major changes: the criminalization of the management of funds derived from the drugs trade, forfeiture of ill-gotten gains, and reciprocal mutual legal assistance. ${ }^{8}$

However, a closer look reveals that in the early discussions leading up to the Forty Recommendations of the Financial Action Task Force on Money Laundering (FATF), ${ }^{9}$ a second goal had already been defined, which aimed at a more rigorous control of routine transactions. This was, of course, the primary concern of countries with large drug-user markets. However, it was evident that the ambitions, especially those of the US delegation to the FATF, went even further; beyond the registration of cash transactions, the suggested measures were intended to reduce drastically the use of cash globally in order to establish a paper trail wherever possible. It is in keeping with the logic of this strategy that one of the major suggestions made by the US delegation in the early days of the FATF was to maintain meaningful statistics on aggregate financial flows in OECD countries. ${ }^{10}$ Clearly, the international minimal standards developed concurrently on 'customer-due-diligence' (CDD) for banks, especially the 'KYC'-principle (know-your-customer), codified first in the Basel Statement of Principles ${ }^{11}$ and integrated into the common standards of the FATF $1990,{ }^{12}$ indicate that the initiative against money laundering was from the outset multi-focused. Beyond tracking criminals and their assets, broader risk management strategies and international regulations for financial markets were anticipated. This motivation comes out even more clearly in later initiatives, most notably the Financial Stability Forum and its report in $2001^{13}$ as well as the current work of the

Cf. note 3, '. . financing of terrorism, terrorist acts and terrorist organisations as predicate offences to money laundering'!

Pieth, Tracking Down the Dirty Money, Financial Times, 25 October 2001, p. 23.

9 FATF, Forty Recommendations, report of 6 February 1990.

${ }^{10}$ Cf. ibid, Documentation Legal and Regulatory Subgroups FATF I.

11 Basel Statement of Principles of 12 December 1988.

12 Cf. supra note 9, FATF Rec. 12-14.

13 Financial Stability Forum, International Standards and Codes to Strengthen Financial Systems, April 2001 
$\mathrm{IMF}^{14}$ that addresses the problems associated with the destabilizing potential of offshore financial centres and the services they offer.

\section{The abolition and re-introduction of asset forfeiture}

Returning to the primary goal - crime control - a rarely discussed development needs to be analyzed. In the beginning, money laundering was not so much a concept to criminalize the behaviour of individuals or legal persons but rather a means of securing the forfeiture of ill-gotten gains. In fact the United Nations' 'Comprehensive Multi-disciplinary Outline of Future Activities in Drug Abuse Control'15 of 1988, the blueprint of the Vienna Convention Against Trafficking in Narcotic Drugs of 1988, ${ }^{16}$ did not mention criminalization as such, but concentrated exclusively on forfeiture.

Forfeiture of assets looks like an old concept and in fact has its roots in the confiscation of the entire assets of a person convicted and executed for major crime ('laesio majestatis', treason, witchcraft and similar offences) in ancient Rome, also later on in the Middle Ages and especially during early industrialization in the period of absolutist rule in Europe.

One thing these regimes had in common was that they used criminal law in a purely utilitarian if not instrumental way, an approach best illustrated by Macchiavelli's views on government in 'Il Principe". The current discourse on forfeiture of assets frequently overlooks the fact that the abolition of confiscation was at least as crucial to the protagonists of early Human Rights declarations and the drafters of the first constitutions in Europe and the Americas during the Age of Enlightenment as the restriction of the death penalty. Absolutists in the 18th century were often unable to raise sufficient funds to meet the costs of their overblown schemes and their penchant for warfare without increasing reliance on loans from the emerging moneyed industrialist class. Under these circumstances, it was occasionally practical to dispossess those winners of the industrialization process, especially as they increasingly demanded their share of political power to match their economic significance. Asset forfeiture was used as an element in the process of criminalization of political opponents. It is hardly then surprising that for those from whom property was confiscated, forfeiture was regarded as an arbitrary tool wielded

14 Developing an IMF-ROSC-Module on money laundering, cf. Neue Zürcher Zeitung, 12 March 2002, p. 27.

is Target 23, p. 63 f: 'Forfeiture of the Instruments and Proceeds of Illegal Drug Trafficking'; the issue of criminalizing money laundering, however, was introduced in Art. 3 of the 1988 Convention and the political declaration of the General Assembly in the GA Res. S-17/2 of 15 March 1990.

16 UN Convention against Illicit Traffic in Narcotic Drugs and Psychotropic Substances ('Vienna Convention') of 20 December 1988. 
by a non-legitimate state with the aim of subjugating and dispossessing them in order to enrich the ruler. Beccaria (Dei delitti e delle bene, 1766, XXV.), for instance, one of the most articulate contemporary protagonists of criminal policy in the 18th century, deplored the irrational aspects of confiscation, which included pushing the innocent (i.e. family members of the dispossessed) into crime.

Confiscation viewed from this angle clearly posed a risk to investment and an infringement on the inviolability of private property. It is no coincidence that some modern constitutions, which are still extensively influenced by the bourgeois revolutions of the late 18 th and early 19 th centuries and to be found in some Latin American constitutions (see Mexico), squarely declare 'confiscation' as unconstitutional. It is noteworthy that 'confiscation' remained a political 'four-letter-word' for nearly two hundred years until it was reinvented in the 1970s. Certainly up until then, the general confiscation of all assets of a convicted person was outlawed because it was considered disproportionate and had far reaching effects on the family of the dispossessed. However, many legal systems retained a certain power to forfeit, although this was generally limited to dangerous objects ('instrumenta sceleris', such as the instruments or weapons used to perpetrate a crime or the products of crime, for instance pornographic paintings) in order to destroy them. Increasingly, it must be added, an effect similar to that of confiscation was achieved by raising the level of fines to siphon off ill-gotten gains. Even nowadays, some legal systems prefer confiscatory fines to the actual confiscation of ill-gotten gains. ${ }^{17}$

Nevertheless, this historical development still does not explain how it was possible to reintroduce confiscation towards the end of the 20th century, including some broad, sweeping forms of forfeiture of all assets ${ }^{18}$ and even the occasional reversal of the burden of proof of legal origin imposed on the owner. ${ }^{19}$ Furthermore, there is the need to clarify why this historical shift back to an old and discredited concept could have been engineered without provoking major intellectual debate. A change of conceptual terminology is discernible in the early 1970 s, when it was increasingly stated that it was inadequate to punish individuals, whilst at the same time allowing them to enjoy the fruits of their illegal behaviour. The issue did not really develop, however, as long as criminal law concentrated on crimes with clearly defined victims who could be granted compensation out of the profits of crime. With the expansion of victimless crimes or crimes against the public interest, especially the criminalization of trafficking in narcotic substances, the issue became increasingly important. Whereas in Europe in the 18th century during the age of absolutist regimes, confiscation was used to dispossess well-to-do citizens who were claiming their share in political power, the new concepts were far more easily legitimized, as they largely

17 So, for instance, the US FCPA does not contain special provisions for criminal forfeiture, similar results could, however, be achieved either by civil forfeiture or a confiscatory fine.

18 Cf. the German 'Vermögensstrafe' and 'Erweiterter Verfall.

19 Cf. Rider, 'The Crusade against Money Laundering - Time to Think!' (1998) Vol. 1 Issue 4 European Journal of Law Reform at p. 518. 
constituted a welcome addition to public income, by way of 'taxing' large-scale illegal activities and organized criminals ('The Mafia', the 'folk-devils' of our time).

\section{Contradictions in controlling drug money laundering}

Forfeiting the gains derived from illegal drug trafficking and, at a later stage, criminalizing those who helped obscure the origins of those gains, was introduced as a narrowly focused tactical concept that pinpointed taking away the profits and thereby reducing the attractiveness of becoming a trafficker. Already at that time, a macroeconomic rationale was put forward in support of the new tactics. The argument was advanced that siphoning off the illegal profits would lead to a rise in the price of the illegal goods and consequently to a reduction in their demand. ${ }^{20}$ This was rather short-sighted reasoning in an area where demand is bound to be highly elastic due to the dependency of a large segment of drug-users who are prepared to procure the necessary funds to finance their habit by all available means. In fact, the effect of the strategy was that it most likely even made the problem all the more acute by boosting the market volume. It raised the attraction of illegal activity since the profits were bound to rise concurrently with the prices, probably even disproportionately so.

The impact of anti-money laundering policies on the drug problem worldwide thus remained very limited. Huge efforts, at immense expense in money and personnel, in both the public and the private sectors were made, yet the number of criminal cases brought ${ }^{21}$ and the amount of profit forfeited ${ }^{22}$ remained small in relation to the estimated funds generated by illegal markets. ${ }^{23}$ The size of the drug problem has, if at all, been affected to a much greater degree by alternative policies than by the military/police approach. ${ }^{24}$ Nevertheless, the production of laws and regulations has not diminished and the regional reach of anti-money laundering concepts has continued to expand.

The discourse shifted and increasingly all funds in the hands of organized crime operators, (whether legally or illegally obtained ${ }^{25}$ ) were declared dangerous, just as 'instrumenta sceleris' had been earlier on, since they increased the ability of such organizations to engage in illegal activities and to come into conflict with the

20 Meier/Dessecker/Smettan (eds.), Gewinnabschöpfung bei Betäubungmitteln (Wiesbaden 1989) at p. 539.

21 Kilchling (ed.), Die Praxis der Gewinnabschöpfung in Europa (Freiburg 2002) at p. 441.

22 Ibid, at p. 444.

$23 \mathrm{Cf}$. the figures published by the UN and their critique in Pieth, Bekämpfung der Geldwäscherei (Basel/Frankfurt 1992) at p. 12.

${ }^{24}$ Cf. Pieth, 'Gefährliche Strategiespiele' in: Plädoyer (1992) at p. 38.

$25 \mathrm{Cf}$. for the more recent of forfeiture of assets under the control of organized crime: UN Model Legislation on Money Laundering 1995 (UNDP) or Art. 59 s. 3 Swiss Penal Code. 
authorities (or, alternatively, bribe them for protection). In a relatively short period of time the international organizations, pushed on by a small group of countries (especially the US, France and the UK), managed to broaden the discussion on money laundering from a limited effort to reduce drug-trafficking to a generalized concept to tackle serious crime. The political mechanisms used for the expansion of the paradigm can be illustrated by the image of concentric circles created by a stone thrown into a pond. The core countries mentioned above convinced the G-7 States. The $\mathrm{G}-7$ States in turn created a specialized body to combat money laundering (the FATF $^{26}$ ) in 1989, which then included the wider framework of OECD countries (and a few non-members), and ultimately formed regional satellites. ${ }^{27}$ The implementation of the strategy was promoted by soft law and peer pressure (monitoring ${ }^{28}$ ), it was only at a later stage that some areas were integrated into binding international law. ${ }^{29}$ Most recently, the UN went over the same terrain again with the largest constituency. ${ }^{30}$

The fact that the effect of anti-money laundering policies probably amounts to little more than a relatively low 'tax' on illegal trade has not impeded the continued production of yet more rules. Instead the focus of the discourse shifted entirely.

\section{The generalization of the concept of money laundering}

With the extension of the scope of money-laundering-offences from drug-trafficking to 'all serious crime', (which was accepted by the FATF in 1996 in the revised edition of its Forty Recommendations) ${ }^{31}$ and its implementation at the national level around the world, now ordinary crimes against property as well as corruption, illegal armstrading, gaming and trafficking in human beings, and so on, are considered predicates.

If this is a perfectly logical step intellectually (why should fraud be less serious than drug trafficking?), neither the authorities, nor the private sector, have fully grasped the practical implications of this widening of the scope of anti-money laundering. On the one hand the sheer volume of 'dirty money' has probably

26

As, for example, the Caribbean Financial Action Task Force, created with the Kingston Declaration of 6 November 1992.

28 Gilmore, Dirty Money: The Evolution of Money Laundering Counter-Measures (Strasbourg 1999, 2nd ed.); for monitoring procedures in general: Pieth, 'From Ideal to Reality: Making the New Global Standards Stick' in No Longer Business as Usual, Fighting Bribery and Corruption (Paris OECD 2000).

29 Cf. the Council of Europe Convention of 8 November 1990 on Laundering, Search, Seizure and Confiscation of the Proceeds from Crime, Strasbourg.

30 UN Convention against Transnational Organised Crime, cf. GA 55/383.

31 Cf. supra note 26. 
doubled, or even tripled, as estimates of the funds generated by corruption (bribes and the profits of bribery) alone are said to equal the profits of the illegal drugs trade. ${ }^{32}$ These additions also extend awareness (red flag lists etc.) to new types of legal risks, even if the actual methodology of laundering may not vary that much according to the predicates. Financial institutions are now forced to extend their vigilance to 'slush funds' held by their largest and best institutional clients (especially multinational enterprises who might get involved in grand corruption). Although the money held in these funds is not actually laundered, it may still be destined for criminal purposes, and for financial institutions, the risk is not so much that of becoming a launderer but of being held liable as an accomplice, if the purpose of a transaction was foreseeable. The impact of the extension of predicates is considerable. Apart from the traditional transaction-related red flag lists, additional factors pertaining to the person (client as well as beneficial owner), his or her place of origin and residence and so on, his or her economic background, the industry-sector involved and so on will all have to be monitored and it would be best to develop a weighted score-table for the new risks identified.

From a more general standpoint it may be said that money laundering is now used as an icon for 'financial crime' as such. Financial crime has developed into a common denominator of all kinds of macrocrime. Organized, corporate and also state-criminals (as well as para-state criminals if one thinks of offences committed by the members of militias) all need funding and most of them need to hide their profits. ${ }^{33}$

Just as legal business entities have maximized the benefits of globalization so too have criminal operators. They are linked up in international networks and can easily transfer their centres of activity and, above all, make use of modern banking technology to transfer their assets. They have proved to be highly proficient in benefiting from regulatory arbitrage, similar to the way companies and individuals optimize their tax situation. Having recruited the help of financial institutions across the world, these operators have succeeded in building so-called structures (combining the assistance of attorneys and other holders of professional privilege with the use of bank accounts located in financial centres with strong bank secrecy and little inclination for giving mutual legal assistance as well as deploying International Business Companies). ${ }^{34}$

32 This figure has repeatedly been quoted by the media as a World Bank estimate. It has, however, not been possible to track down the original source. Nevertheless, it can be assumed that the dimensions of funds generated both by bribes and the profits of bribery are huge.

33 Pieth, Working paper presented at the 10th UN Congress on the Prevention of Crime and the Treatment of Offenders, Vienna, 10-17 April 2000, plenary meeting on international co-operation in combating transnational crime: New challenges in the 21 st century.

34 'Paradis financier, secret bancaire et blanchissement d'argent' United Nations, New York 1999. 
Jonathan Winer has in this volume ${ }^{35}$ pointed out that there is an inherent risk of the banking community being used for these purposes and that part of the problem is the organization of banking supervision at the national level when financial institutions operate globally. This takes us back to the regulatory concepts that have developed in parallel to criminal law over the last decade.

\section{The slow development of 'customer-due-diligence' (CDD)}

In 1988, when the Basel Committee on Banking Supervision (BCBS) wrote the Basel Statement of Principles ${ }^{36}$ and introduced the concept of 'KYC' (know-yourcustomer) as a fundamental principle in banking supervision, the aim was far broader than 'catching criminals'. The principle sought first to facilitate credible risk management by financial institutions, and secondly to reduce the risks of uncontrolled money flows worldwide. If this last point had not yet clearly emerged, it certainly was part of the motivation for upgrading these principles in a fundamentally new code, the BCBS's new code of 'Customer-Due-Diligence for Banks' of October 2001, discussed in greater detail by Charles Freeland in this volume. ${ }^{37}$ These efforts are closely linked to the work of the Financial Stability Forum $^{38}$ and its successors in the IMF. ${ }^{39}$ Beyond combating money laundering, these obligations on customer acceptance and their continuous monitoring are part of an attempt at harmonizing standards in banking supervision as a reaction to the demise of national control by using elements of global governance for financial centres. Of course, more detailed rules on CDD are only one aspect within a wider framework, and the next steps due in this development are still quite undefined.

It is, however, significant that the FATF was not really in the position to give more detailed guidance between 1990 and about 1999 on customer due diligence. All the excitement about the Non Co-operative Countries and Territories process, the blacklisting and partial de-listing of so-called 'NCCTs', has overshadowed the fact that many FATF core-members were not ready to implement even basic customer due diligence standards at the levels already defined in the 1990 recommendations. ${ }^{40}$

35 See J. Winer, Globalization, Terrorist Finance, and Global Conflict - Time for a White List?' in (2002) 4 European Journal of Law Reform (in this issue).

36 Cf. supra note 11 .

37 C. Freeland, "How Can Sound Customer Due Diligence Rules Help Prevent the Misuse of Financial Institutions in the Financing of Terrorism?' in (2002) 4 European Journal of Law Reform (in this issue).

38 Cf. supra note 13.

39 Cf. supra note 14.

$40 \mathrm{Cf}$ as an example: Financial Action Task Force on Money Laundering, Second Mutual Evaluation Report on the United States, FATF VIII, 21 March 1997. 
The lack of clear international guidance on identifying 'beneficial owners' is an example of this period of stagnation.

New developments were set in motion by various international initiatives. In 1997 the OECD Working Group on Bribery wrote its Convention on Combating Bribery in International Business Transactions. ${ }^{41}$ As part of the concluding act, the Council of the OECD decided to go beyond this convention and discuss the abuse of financial resorts (especially OFCs) for the purpose of facilitating bribery and bribemoney laundering. ${ }^{42}$ Work on this topic very soon focused, at least in part, on customer due diligence. Concurrently, and not unrelated to the process, 13 major international banks and the NGO 'Transparency International' decided to develop a private code of conduct, the 'Wolfsberg Principles'. ${ }^{43}$ Probably their most significant effect was to provoke regulators, who had already started work on new rules on CDD within the BCBS, into adopting a more rigorous approach. As was to be expected, the CDD paper of the BCBS would in turn influence the FATF recommendations which have also been under revision since 2000 and are due to be published in October 2002.

\section{The impact of 11 September 2001}

The foregoing is a description of the state of affairs prevailing when the events of 11 September occurred and completely changed perceptions of terrorism worldwide. During the period immediately following the attacks, governments and international organizations working on this subject grappled mainly with the differences between money laundering and the financing of crime. ${ }^{44}$ It was maintained correctly that much of the money used to finance terrorist operations could have legal sources, and that therefore different concepts should be applied. The FATF tried to short-circuit this by a daring, if intellectually untenable, assertion: by calling the financing of terrorism 'money laundering', the tedious discussions and new concepts seemed to become unnecessary. Armand Kersten rightly criticizes this approach in this volume ${ }^{45}$ Nevertheless, concepts need to be in place to criminalize the intentional acceptance and the management of such funds which are to be subject to forfeiture and must also be included in the anti-money laundering notification schemes. ${ }^{46} \mathrm{It}$

OECD: Convention on Combating Bribery of Foreign Public Officials in International Business Transactions, 21 November 1997.

44 Cf. supra note 3, FATF Special Recommendations on Terrorist Financing.

45 A. Kersten, 'Financing Terrorism - a Predicate Offence to Money Laundering?' in (2002) 4 European Journal of Law Reform (in this issue).

46 Cf. supra note 8 . 
will almost certainly be more difficult for banks to identify such funds compared to those of other high risk clients because the red flags pointing to the criminal origin will have to be re-assigned. In this context, financial institutions are even more dependant on official lists of names than they would be, for instance, in the case of drug-traffickers. ${ }^{47}$ One might therefore say that the awareness concepts used to detect the monies of terrorists have far more in common with the formal approach used in embargo cases than with the usual increase in diligence with respect to unusual circumstances or critical client segments.

With the passage of time since the attacks, however, what emerges is that at a technical level risk management in connection with the financing of terrorism is not all that different from managing other, more traditional, risks. The principal lesson we can draw from 11 September is that it would be a good idea to finally implement the basic concepts against money laundering. The section of the US PATRIOT Act ${ }^{48}$ referring to new rules for financial institutions to a large extent covers traditional ground, and issues which could not be implemented previously on account of political opposition under the former US administration ${ }^{49}$ have now passed into law.

\section{Where are we going?}

The events of 11 September have certainly shocked legislators into action. Some of the laws against terrorism enacted quickly all over the world, have little more than symbolic value, much of what has been addressed in the financial field was already in the pipeline well before the attacks. Legislation on KYC that was formerly considered impossible is suddenly acceptable.$^{50}$ Furthermore, it is now possible to speed up legislation and regulation in previously targeted areas like correspondent banking. ${ }^{51}$ This could also be the moment to re-evaluate more thoroughly the question which of the recommendations of the FATF remains too unspecific. To some extent the Wolfsberg principles or, even more apposite in connection with this issue, the BCBS's CDD-Recommendations address the question of thorough identification of 'beneficial owners', including beneficiaries of trusts and corporate

47 Cf. supra note 2.

48 Cf. supra note 1, US PATRIOT Act, Sec. 301 ss.

$49 \mathrm{Cf}$. the difficulties of the previous administration in passing more stringent anti-moneylaundering rules under the Chairmanship of Senator Levin; the last minute agreement of the New York Clearing House Association under the Chairmanship of Undersecretary Eizenstat and the initial reluctance of the new administration (Spokesperson: Secretary of the Treasury Paul Henry O'Neill) on introducing tougher anti-money-laundering legislation.

so Cf. supra notes 48 and 49.

51 Cf. already the New York Clearing House Association Guidelines and the Patriot Act. 
vehicles, on the basis of 'satisfactory evidence'. 52 This direction is a welcome addition to the up-to-now, rather superficial obligation of clients simply to name the beneficiaries. The identification of beneficiaries is probably one of the key topics in the current development of anti-money laundering systems. In parallel to the blacklisting of 'NCCTs', it would be worthwhile to do a better job in the world of regulated banking (roughly comprising the OECD Member States) to prevent the uncontrolled influx of assets from under-regulated centres outside the area (the 'cordon sanitaire'-model).

Up to now, the main focus of this text has been the technical development of money laundering principles. It is time to place the discourse in a wider context. It has already been stated that money laundering is increasingly turning into an 'icon' of financial crime in general and that it is closely linked to all forms of organizational crime (including organized, state and corporate crime), be it Mafia-type activities on illegal markets, the plundering of natural resources, environmental crime, corruption, terrorism or even genocide. Organizational crime is typically transnational and usually maintains its activities over an extended period of time. In order to keep going, it is dependant on a business-orientated, financial and administrative management structure. Of all forms of organizational crime, terrorism is probably one of the least cost intensive. Nevertheless, the use of financial institutions is crucial to these types of crime.

Jonathan Winer in his paper rightly points out that contrary to the position of many banks and bankers, moving money from country to country, disguising its origins and enabling its use for criminal purposes is not a morally neutral activity'. ${ }^{53}$ Financial institutions all over the world have been used to prolong and deepen the plight of the victims of these practices, especially that of the population of developing countries in the South. There have been countless financial scandals in connection with potentates who have plundered their countries' coffers, who have received exorbitant bribes which will have to be repaid by the already impoverished citizens of their states. Money laundering, however, is being conceptualized more and more as a means of repatriating stolen goods. Conceptual terminology gives the fight against money laundering a distinct emancipatory ring, thus creating strong ethical grounds for pressurizing financial centres and institutions to follow strict customer due diligence guidelines.

Whilst breaking the power of undemocratic leaders and their accomplices in the financial world may help to quell the anger of dispossessed populations from which terrorists are frequently recruited, an all-out war against the financing of terrorism could backfire, even if it appears to be the logical consequence of what has been said so far. If money laundering is increasingly used as an 'empty concept' that is arbitrarily adapted, and possibly were to go as far as attempting to gain control over

52 Basel Committee on Banking Supervision, Customer Due Diligence for Banks, October $2001, \S 32$ ss. (p. 8).

53 Cf. supra, note 35 at p. $\mathbf{x x}$. 
money flows worldwide - as if this were even feasible - then the idea of using it to track down any political opponent would make the concept at risk of being regarded as an oppressive tool. It is unfortunate that there is almost no intellectual debate currently as to what constitutes 'terrorism'. This makes it even easier for politicians to fill the gap - for example by the EU Council in its Common Positionf ${ }^{54}$ adopted at the end of 2001. This document defines a 'terrorist act' in terms of the sort of crimes one would expect, but then goes on to include intentional acts; 'causing extensive destruction to an information system, [or] a fixed platform located on the continental shelf ... resulting in major economic loss'. If terrorism is to encompass hackers and organizations that protest in the North Sea then - to put it somewhat bluntly - the efforts to fight money laundering become part of the problem as well. They are at risk of being perceived as instruments of repression and terror and not only nurture the anger of those who are already disaffected with society but also alienate the average citizen as well. There is still time however, to re-define the goals of antimoney laundering initiatives and give their instrumentation the necessary contours.

${ }^{54}$ Council Common Position 2001/931/CFSP on the application of specific measures to combat terrorism OJ 2001 L 344/93. 